\title{
THE SECRET LIFE OF THE PRIVATE ATTORNEY GENERAL
}

\author{
JEREMY A.RABKIN* \\ । \\ INTRODUCTION
}

The "private attorney general" came out of the shadows in the 1970s. In 1943, when the phrase first appeared in a federal appeals court ruling, army generals commanded a lot more attention than any form of attorney general. For decades thereafter, the term was an isolated oddity in the case reports. ${ }^{1}$ Then in the 1970s, the term seemed to be everywhere. With sympathetic nurturing from courts and Congress, this form of legal advocacy seemed for a time to be a powerful engine of public policy. Over the past decade, however, the "private attorney general" has been in retreat, beset by critics and rivals and increasingly starved of resources and political support. If not quite back in the shadows, it is certainly under a cloud.

In retrospect, neither the earlier obscurity nor the current climate of disfavor are very surprising. R ather, what seems incongruous is the general approbation for the private attorney general during the 1970s. A fter all, the phraseand the thought behind it-are inherently disorienting. The "private attorney general" is someone who is understood to be suing on behalf of the public, but doing so on his own initiative, with no accountability to the government or the electorate. For most of this century, public administration experts urged that the federal government needed to be made more accountable to the chief executive. In this context, the notion of a "private attorney general" would have struck most observers as an oddity on a par with a "private government" - or a private general.

But the era when the "private attorney general" flourished was a peculiar time. There were still great hopes for government, as evidenced by a flood of new federal regulatory programs. A the same time, the nation experienced an intense distrust of government and a relentless pursuit of scandal allegations, which ultimately drove an elected President from office for the first time in A merican history. In this climate, courts lowered standing barriers, allowing

\footnotetext{
Copyright (C) 1998 by L aw and Contemporary Problems

This essay is also available at http://www.law.duke.edu/journals/61L CPR abkin.

* A ssociate Professor of G overnment, Cornell U niversity.
}

1. In the 25 years following its first use, the term appeared in only eight federal district court opinions and 11 court of appeals decisions (according to a LEXIS search). By contrast, between 1972 and 1977, the term appeared in 256 district court opinions and 167 court of appeals decisions. In the period between 1992 and 1997, it appeared in 237 district court decisions and 115 court of appeals decisions. 
advocacy groups to bring a wider range of "issues" into court. Congress authorized "any citizen" to enforce new environmental protection laws; ${ }^{2}$ other measures encouraged issue-oriented litigation, especially new provisions on attorneys fees. ${ }^{3}$ The culmination of the trend came in 1978, when Congress authorized courts to appoint private attorneys as special prosecutors to investigate wrongdoing by high executive branch officials. ${ }^{4}$

A fter its decade in the sun, however, the "private attorney general" began to wilt. The phrase appeared less often in case reports; the concept came to be regarded with much less favor in the courts and in Congress. Part of the change seems readily explained by shifting political winds: A s prevailing opinion became less sanguine about government programs, it also became less sympathetic to private advocates trying to advance public mandates - rather than their own distinct rights-through the courts.

B eneath this evident trend was another, subtler pattern. The abstract term implies that the "private attorney general" could be almost anyone-an ordinary citizen, perhaps, with just a bit more public spirit than his neighbors. The truth was always different. The "private attorney general" was in favor when judges-and members of Congress-were most sympathetic to the particular advocacy groups expected to fill the role. Courts even erected legal fences to ensure that the role was filled by the preferred advocates where the role of the "private attorney general" was most salient. The "private attorney general," in other words, always had implicit public patronage.

A s new issue advocates emerged in the past two decades and the prevailing political climate became more contentious, courts backed away from the earlier pattern. They are now distinctly less inclined to provide favored access to favored advocates. The role of the "private attorney general" has diminished accordingly. For lawyers today, it is far less inviting to play the role of "private attorney general" than it was in the 1970s.

\section{Special Public A dvocates: Two Modelsor One?}

The term "private attorney general" should probably be reserved for the actual party in a special kind of lawsuit. But the term is often used to refer to the attorney in the case. In current case reports, the term most often appears in disputes about attorneys fees, where the claim is that the attorney deserves special fee consideration because his case has performed a public service. In many cases, moreover, the attorney-or the public interest law firm for which he works-is the actual party of record.

2. See, e.g., 33 U .S.C. § 1365(a)(2) (1994) (W ater Pollution Control A ct); 42 U .S.C. § 4911(a)(2) (1994) (Noise Control A ct); id. § 7604.

3. See, e.g., 42 U .S.C. § 1988 (1994 \& Supp. II 1996) (Civil Rights A ttorneys Fees A wards A ct of 1976).

4. See 28 U.S.C. $\S \S 49,591-99$ (1994) (E thics in G overnment A ct). 
There is also a deeper reason for this ambiguity about the meaning of the term. A Imost by definition, the precise client in a public interest lawsuit is hard to determine. If the private attorney general speaks for the public, then it would seem that the public is the true client-or that no one in particular is the client. The term deflects attention away from the precise rights or particular interests of the moving party, encouraging instead a focus on the general claims about "the law" or "the issue" which the lawsuit raises.

The notion of a "private attorney general" is most attractive, then, when it is most clear that "the law" should be implemented or enforced-so that we do not need to ask at whose behest or on whose behalf. When does the law present this sort of transcendent imperative? In the aftermath of the Watergate scandals, Congress was readily persuaded that criminal misconduct by high executive officers, including the President, would present such a case. The E thics in Government A ct accordingly provided that evidence of almost any criminal transgression by high executive officials should trigger the appointment of an Independent Counsel. A s late as 1988, only J ustice Scalia found constitutional difficulties with this arrangement. ${ }^{5}$

The institution has taken a different color in the ongoing controversy over the actions of Independent Counsel Kenneth Starr. D efenders of President Clinton hint darkly that this Counsel is not truly independent but is rather an instrument of "the right-wing conspiracy" or of "partisan R epublicans" or even of "the tobacco industry." But such claims are beside the point. O nce a political campaign was mounted to challenge the Independent Counsel, his decisions were bound to look suspect. The Independent Counsel is not appointed by the elected President nor is he subject to easy removal by the President. $\mathrm{H}$ is only legitimacy derives from judicial sanction. That no longer seems enough to many observers.

Should the Independent Counsel have forced Secret Service agents to testify against the President? Should he have subpoenaed bookstore records to determine the reading habits of M onica L ewinsky? Should he have devoted so much attention to the possibility of a presidential affair with a twenty-one year old intern? Federal judges directly sanctioned every one of these practices. To critics, however, the issue is not whether the actions of the Independent Counsel are "legal," but whether he should really have exercised every point of leverage that the law allows.

There is, of course, an inescapable degree of partisanship in all of this. The most vocal critics of $\mathrm{K}$ enneth Starr have been those most sympathetic to President Clinton. Few, if any, of these critics found fault with previous Independent Counsels, when prosecutorial zeal was turned on R epublican administrations. It would be overly cynical, perhaps, to attribute partisan motives to every recent critic of the institution of the Independent C ounsel. N onetheless, the late date at which many critics discovered their objections suggests that

5. See M orrison v. O Ison, 487 U .S. 654, 697 (1988) (Scalia, J., dissenting). 
they had previously viewed the institution in a rather different light. They probably had assumed that Independent Counsels would only be used to investigate a president like $\mathrm{Nixon}$ by a prosecutor like $\mathrm{A}$ rchibald $\mathrm{Cox}$-in whatever vague or hazy terms (and to whatever explicitly and consciously partisan degree) these categories were defined. ${ }^{6}$ Such critics have seen the Clinton case differently.

The Independent Counsel is, almost literally, an alternate A ttorney General. Since the Independent Counsel is not appointed by the President and is permitted to pursue a private law practice while performing special prosecutorial duties, one might even describe the Independent Counsel as a "private attorney general." $Y$ et among the current critics of the Independent Counsel are some scholars who have in the past been staunch defenders of the "private attorney general" in other areas of litigation.?

Is this because the Independent Counsel has broader powers and can therefore have a more disruptive impact on public policy or public authority? But the counsel's powers remain bounded by limits enforced by courts. Courts are the ultimate check (and the ultimate motor) of the private attorney general, too. Is the difference, then, that the Independent Counsel is now seen as someone who is determinedly partisan? Could that not be true of the private attorney general as well? Or could it?

In truth, sympathy for the "private attorney general" in other contexts does not reflect any expectation that a random assortment of parties- or a cross section of possible plaintiffs-will come forward to litigate as private attorneys general. On the contrary, the underlying assumption is that in each particular area, the private attorney general will be a known quantity, reflecting a wellestablished interest or constituency.

This was the guiding assumption in the case that launched the term "private attorney general." Judge J erome Frank coined the term in A ssociated Industries v. Ickes, ${ }^{8}$ a 1943 Second Circuit case that arose in the context of a New Deal regulatory scheme. U nder the Bituminous Coal A ct of $1937,{ }^{9}$ coal producers were authorized to establish minimum prices, subject to approval of a National Coal Commission. A separate official, the Coal Consumers Counsel, was authorized to challenge decisions of the Commission by a review petition in federal appellate court. A ssociated Industries represented commercial firms

6. See, e.g., Elizabeth Holtzman, N ot Why We Wrote the Act, N.Y. TIMES, A ug. 10, 1998, at A 15 ("I never dreamed that a special prosecutor would be using his enormous powers to investigate accusations about a President's private (and legal) sexual conduct. We acted against the background of the Watergate affair, which involved serious crimes, including an illegal break-in."). Former R ep. H oltzman does not give any clear explanation why obstruction of justice to cover up a burglary is a serious crime, while obstruction of justice to cover up perjury by the President himself in a sexual harassment suit should be brushed aside.

7. Compare Cass R. Sunstein, Unchecked and Unbalanced: Why the Independent Counsel Act M ust G o, A M. PR OSPECT, M ay-J une 1998, at 20, with Cass R. Sunstein, What's Standing A fter Lujan? Of Citizen Suits, "I njuries” and A rticle III, 91 M ICH . L. R EV. 163 (1992).

8. 134 F .2d 694 (2d Cir. 1943), vacated on suggestion of mootness, 320 U .S. 707 (1943).

9. 15 U .S.C. §§ 828-52, repeal ed by Pub. L. N o. 89-554, § 8(a), 80 Stat. 649, 651 (1966). 
which were heavy users of coal. The precise question before the court was whether A ssociated Industries could have standing to challenge a price increase by the Coal Commission when the government's Coal Consumers Counsel had declined to do so.

In 1943, standing to sue was a strange and confusing doctrine. The word always appears in quotation marks in J udge Frank's opinion, as if it were a foreign or disputed term. The difficulty, J udge Frank argued, is that standing implies a focus on the plaintiff's right to sue apart from the merits of his claim. ${ }^{10}$ But the traditional understanding of the merits is precisely whether this plaintiff has suffered injury to his rights in such a way that he is entitled to relief.

Congress, however, could authorize the A ttorney $G$ eneral to sue on behalf of the general public. Therefore, reasoned Judge Frank, Congress also could enact a statute "conferring on any non-official person, or on a designated group of non-official persons, authority to bring a suit... even if the sole purpose is to vindicate the public interest. Such persons, so authorized, are, so to speak, private A ttorney G enerals [sic]." ${ }^{11}$ The relevant statute authorized "any person aggrieved by an order issued by the Commission in a proceeding to which such person is a party" to seek judicial review of the Commission's decision. A ssociated Industries had been invited to offer its views at the hearing, so Judge Frank dismissed the government's concern that allowing A ssociated Industries to challenge the Coal Commission's conclusions in court would open "possibilities of separate law suits by hundreds of thousands of individual consumers. ..." 12 The Coal Commission could limit appeals by limiting participation in the Commission's own hearings. ${ }^{13}$ The "private attorney general" thus was conceived originally as a private advocate with distinctive public backing.

Thirty years later, in A ssociation of D ata Processing Service O rganizations v. Camp, ${ }^{14}$ the Supreme Court generalized this approach by interpreting the

10. Talking of a right to sue is "not too felicitous," as Frank notes in a trenchant footnote: for anyone has, in a certain sense, a "right" to bring any kind of suit in any court; a man can institute an original action for divorce in the Supreme Court; his suit will be dismissed but he will only suffer costs, just as he would if he brought a suit in a court of proper jurisdiction and lost on the merits.

$134 \mathrm{~F} .2 \mathrm{~d}$ at 700 n.6. In other words, it is strange to talk of a "right to sue" that is separate from "the merits," since the real question, once the court focuses on the case, is "the merits."

11. Id. at 704 (emphasis added).

12. Id. at 707 .

13. See id. at 710-12. Curiously, the opinion does not leave the matter entirely to the Commission, since there might

be a case where, by a blunder, the Commission had permitted a person to become a party to its own proceeding who, as the record facts showed, was unquestionably not an "interested person"; in such event it might be true that such a person could not be treated as a "person aggrieved" under [the statute].

Id. at 712. The opinion is far from clear about why "that question is not now before us." Id.

14. 397 U .S. 150 (1970). J ustice Douglas' opinion cites A ssociated Industries for the proposition that a plaintiff may argue on behalf of the public interest as a "private attorney general." See id. at 153. It is probably more than coincidence that both of these decisions deal with industries projecting themselves in a trade "association": the logic is that of a cartel, where the law parcels out benefits to particular interests, interchangeable within this category-as in a government-sponsored cartel, the coal industry under the Coal A ct. The thought seems to have been that if one set of beneficiaries is 
A dministrative Procedure A ct provision that "any person aggrieved" can seek judicial review as creating a right to appeal as a "private attorney general." ${ }^{15}$ The Court assumed that only certain kinds of advocates could serve as private attorneys general: A would-be plaintiff must establish that he had sustained damage to an interest which was "arguably within the zone of interests to be protected or regulated by the statute... in question." ${ }^{16}$ This formulation blurred the distinction between the "legal interest" of a party with rights at stake and the "political interest" of a constituency expecting certain benefits from the statute. The ambiguity left room for courts to hear complaints about generalized illegality-but only from proper advocates for the relevant legality.

This approach to standing was not very far removed from the scheme endorsed in A ssociated Industries. The premise of much $\mathrm{N}$ ew $\mathrm{D}$ eal regulation was that the public interest requires the accommodation of established interests. Such was the scheme of the Coal A ct: leading coal producers negotiate among themselves to establish the pricing policy that would be in the public interest. When the Supreme Court was still battling against the N ew D eal, it had struck down a very similar scheme as improperly delegating public authority to private interests. ${ }^{17}$ J udge Frank, a staunch N ew Dealer, sought to check the potential for abuse by allowing another selected interest to sit at the table with the coal companies-the "private attorney general" recognized by the government as a proper interest to take part.

By the late 1960s, critics of regulatory agencies complained that they were often "captured" by the regulated interests and were not paying enough attention to underrepresented interests. The response was to broaden the concept of the "private attorney general," while retaining the original meaning. It was understood-not least by courts- that only a "proper" advocate, could be a private attorney general.

III

\section{THE NATURE OF ENVIRONMENTA L ENTITLEMENTS}

The private attorney general has received the most attention in the citizen suits authorized since the 1970s in environmental protection legislation. This litigation has generated a disproportionate share of controversy and been the focus of recent efforts to cut back suits by private attorneys general. Such public advocacy litigation, however, does not always require express statutory authorization for citizen suits; it does not even require a specific statutory scheme of control.

this way, the others should be, too, with one set of organized interests facing another set of equally organized interests. By extension, we get "consumers" represented by an "association" (or one might say, "union") of similarly situated firms or similarly thinking interest group advocates.

15. Id. at 153-54.

16. Id. at 153 .

17. See Carter v. Carter Coal C 0., 298 U .S. 238 (1936). 
Environmental protection statutes of the last three decades may appear novel, if one views their citizen standing provisions as implementing an "entitlement" to clean air, clean water or a safe environment. B ut a different kind of environmental entitlement was already at the heart of the $\mathrm{New} D$ eal regulatory programs. In essence, price and entry controls on regulated business sought to provide a stable business environment-for regulated industries, for their firms, for their competitors, for their suppliers and consumers. A s the ambition of administrative control expands, the question of what interests have a claim to be considered becomes more and more pressing-and more complicated. It is the nature of environmental entitlements that all sorts of people may be affected by the controls, since the same environment surrounds them all. O ften, it is equally uncertain who needs to be controlled to secure this environment as who will benefit or should benefit: A n environment is not easily disentangled into its components.

The open-ended character of environmental entitlements is most evident if one compares them with traditional common law rights. A t common law, there is normally no question about who may sue and against whom. No one sues to vindicate property rights or contract rights in the abstract or to vindicate an "interest" in someone else's rights. O nly the holder of some particular property or contract right may sue, and he may only sue the person who has violated his right. While common law rights are often said to have a universal or abstract character, what this means is that a court need not concern itself with what any particular right holder does with his rights. O verall social outcomes are not at stake in any particular litigation.

A dministrative regulation reflects an ambition to control various kinds of environments in a more reliable and more precise way. The holder of a common law right can choose to waive it. He can allow trespassers onto his property or choose not to enforce his contract rights. A n environmental entitlement must be enforced collectively. A n environmental entitlement therefore necessarily raises questions about who gets to enforce it and on whose behalf. Such questions did not arise only in disputes about who might claim to hold (or to be) an "aggrieved interest" under statutory regulatory programs; constitutional litigation raised similar questions by the 1960s.

\section{A. The E stablishment Clause}

A good example is the E stablishment Clause of the First A mendment. ${ }^{18}$ In 1947, when the Supreme Court first extended this constitutional prohibition to state and local governments, it interpreted the clause as mandating government neutrality. ${ }^{19}$ Who was entitled to enforce this entitlement to an environment of

18. See U S. CONST. amend. I ("Congress shall make no law respecting an establishment of religion...").

19. Everson v. Board of Education, 330 U S. 1 (1947), was the first case to hold that the Establishment Clause applies to the states (and hence to local school districts): It affirmed that the clause "requires the state to be neutral in its relations with groups of religious believers and non-believers." Id. at 18. Lemon v. Kurtzman, 403 U.S. 602 (1971), the first case to strike down aid to religious 
official neutrality? When the Court struck down school prayer in 1962, its decision said almost nothing about the plaintiffs' standing to bring this challenge. ${ }^{20}$ Some commentators accordingly speculated that the Court was endorsing a "public action" under which any citizen could challenge deviations from the command of the E stablishment Clause. ${ }^{21}$ The Court never expressly endorsed this notion, however, and in subsequent cases, merely emphasized the special interests of school children and their parents. The Court also permitted taxpayers to challenge government aid to religion-but disallowed taxpayer standing to challenge other government practices or expenditures. ${ }^{22}$

In effect, the Court conferred the environmental entitlement to government neutrality in religious matters on a particular constituency-those concerned about government endorsement of religion. The litigation privilege was not available to anyone with First A mendment neutrality concerns. It was particularly reserved for opponents of religion or opponents of government "entanglement with religion." R eligious parents protesting school policies that seemed to mock religious values, on the other hand, found their cases thrown out of court on summary judgment. ${ }^{23}$ B oth sides could not invoke the environ-

schools, held that the Establishment Clause means the state "may neither advance nor inhibit religion." Id. at 612-13.

20. See E ngel v. V itale, 370 U.S. 421 (1962). From the outset, Engel emphasized the distinctive character of E stablishment Clause litigation: "The Establishment Clause, unlike the Free Exercise Clause, does not depend on any showing of direct governmental compulsion." Id. at 430. In other words, those seeking to bring E stablishment Clause challenges would not need to show the sort of infringement on personal liberty or property that would be required in conventional litigation. The Court re-emphasized the point the following year in A bington School D istrict v. Schempp, 374 U .S. 203 (1963), when it disallowed Bible readings in public schools, even where dissenting students were given the option not to participate: "[A ] violation of the Free Exercise Clause is predicated on coercion while the Establishment Clause violation need not be so attended." Id. at 223. In other words, there is an environmental entitlement for those seeking to enforce the $\mathrm{E}$ stablishment Clause but not for the Free Exercise Clause. The opinions do not explain the historical or structural basis of this asserted distinction between the clauses.

21. See Louis L. Jaffe, Judicial Control of Administrative Action 497-500 (1965); E rnest J. Brown, Q uis C ustodiet I psos Custodes?-The School Prayer Cases, 1963 SU P. CT. R E V. 1.

22. Flast v. Cohen, 392 U.S. 83 (1968), articulated a standard for taxpayer standing. The Flast standard was not applied in U nited States v. Richardson, 418 U .S. 166 (1974), or Schlesinger v. Reservists, 418 U .S. 208 (1974); it seems never to have been accepted in relation to any other constitutional provision except the Establishment Clause, thus highlighting the special character of Establishment Clause challenges.

23. See, e.g., B rown v. Hot, Sexy, and Safer Prods., 68 F.3d 525, 529 (1st Cir. 1995) (rejecting challenge to A IDS education program in public schools which "advocated and approved ... homosexual [activity] and ... promiscuous premarital sex"; "encouraged a male minor to display his "orgasm face' ... for the camera;" "informed a male minor that he was not having enough orgasms;" "used profane, lewd and lascivious language to describe body parts and excretory functions;" "simulated masturbation"). The Court dismissed the complaints of the parents and their fifteen-year old children who were required to take part in this program on the grounds that "[i]f all parents had a fundamental constitutional right to dictate individually what the schools could teach children, the schools would be forced to cater a curriculum for each student whose parents had genuine moral disagreements with the school's choice of subject matter." Id. at 534. Similarly, Fleischfresser v. D irectors of School District 200, 15 F.3d 680 (7th Cir. 1994), summarily dismissed an E stablishment Clause challenge to elementary school textbook series which (according to the complaint of the parents) "indoctrinates children in values directly opposed to their Christian beliefs." M ozert v. H awkins County B oard. of Education, 827 F.2d 1058 (6th Cir. 1987), summarily dismissed claims of Fundamentalist parents protesting a curriculum that gave favorable notice to witchcraft and non-W estern religions but seemed to slight tradi- 
mental entitlement of government religious neutrality. The point is not that the Court played favorites. It is that the nature of an environmental entitlement requires some distinctions about who gets to invoke it.

While the underlying asymmetry remains, the Court began to compromise the logic of privileged access in the 1980s, just as it began to waiver on the scope or rigor of the underlying entitlement. The Court allowed religious plaintiffs to complain that they had been denied access to school facilities (usually for voluntary, non-classroom events). ${ }^{24}$ Successful plaintiffs did not complain about the general atmosphere in schools, seeking to enforce their own version of the environmental entitlement reserved for secularists. Instead, they complained about improper discrimination that affected them directly. N onetheless, the Court's willingness to endorse such claims put some brake on pressures from strict separationists to exclude any religious presence in public schools- even if private or voluntary. The Court no doubt understood that this also would weaken, to some extent, the force of the environmental entitlement wielded by strict separationists. In the same period, the Court rebuffed some challenges brought by separationists, acknowledging that the Establishment Clause should be interpreted with flexibility and with some regard for longstanding civic traditions.

\section{B. Civil Rights}

A similar pattern of privileged enforcement was once quite evident in civil rights litigation but has eroded rather substantially in the past decade. By the early 1970s, school desegregation cases seemed to imply something like an environmental entitlement to an integrated education. ${ }^{26}$ A s late as 1978, the Supreme Court was hopelessly divided on the question of whether nonminority students had constitutional protection from discrimination, when such dis-

tional Christian belief. The concurring opinion by Judge Boggs emphasized that "under the Supreme Court's decisions as we have them," a school board faces "no limitation on its power to require any curriculum, no matter how offensive or one-sided and to expel those who will not study it, so long as it does not violate the E stablishment Clause" by requiring endorsement of a specific religious doctrineon the assumption that an anti-religious doctrine is not, itself, a religious doctrine. Id. at 1073 (Boggs, J., concurring). Thus "J ewish students may not assert a burden on their religion if their reading materials overwhelmingly provide a negative view of J ews or factual or historical issues important to J ews, so long as such materials do not assert any propositions as religious truth. ..." Id. at 1080 (B oggs, J., concurring). Similarly, Grove v. M ead School District N o. 354, 753 F.2d 1528 (9th Cir. 1985), summarily dismissed an $\mathrm{E}$ stablishment Clause challenge to school textbooks said to embody the religion of "secular humanism" - even if, as the concurring opinion by Judge Canby concedes, secular humanism may be a religion and the books in question may embody its moral teachings and receive implicit endorsement from the schools. See id. at 1535-38 (Canby, J., concurring).

24. See W idmar v. V incent, 454 U .S. 263 (1981) (allowing student prayers on public college campus); Board of E duc. v. Mergens, 496 U.S. 226 (1990) (allowing extra-curricular religious group in public high school); R osenberger v. U niversity of V a., 515 U .S. 819 (1995) (requiring university to finance religious student publications along with others).

25. See L ynch v. D onnelly, 465 U .S. 668 (1984) (allowing display of Christmas creche in city park); M arsh v. Chambers, 463 U S. 783 (1983) (allowing state-employed chaplain to lead prayers at opening of legislative sessions).

26. See, e.g., K eyes v. D enver Sch. D ist., 413 U .S. 189 (1973) (Powell, J ., concurring) (arguing for explicit recognition of such a constitutional entitlement). 
crimination was undertaken for the sake of extending or enhancing integration. ${ }^{27} \mathrm{~A} n$ entitlement to racial integration could not very well coexist with an individual right to race-neutral treatment. L ower courts thus drew the plausible conclusion that white applicants should not have standing to complain about affirmative action programs, not at least where their only complaint was about the principle of differential treatment; the Supreme Court seemed to approve. $^{28}$ A different approach to standing was, of course, evident in cases brought by established civil rights advocacy organizations on behalf of minority students, ${ }^{29}$ consistent with the notion of an integration entitlement.

In 1993, however, the Supreme Court held that the mere denial of the right to compete is a sufficient "injury" to launch a lawsuit. ${ }^{30}$ If a government regulation had explicitly excluded minority candidates from certain programs, no one would have imagined that the law of standing could be invoked to insulate such a regulation from attack. That was, however, the exact ruling of the Eleventh Circuit with respect to nonminority applicants to a program which excluded them from competing. ${ }^{31}$ When the Supreme Court demolished this procedural hurdle, it clearly signaled a new seriousness about the underlying principle. The following year, in A darand Constructors v. Pena, ${ }^{32}$ the Court emphasized that racial preference programs must receive "strict scrutiny" to ensure that they are "narrowly tailored measures that futher compelling governmental interests." ${ }^{33}$ In employment discrimination cases, as well, lower courts had held that an employer's preference scheme could not be challenged by white applicants if the scheme had been adopted in the settlement of a discrimination complaint by minority applicants. In its 1989 ruling in Martin v. Wilks, ${ }^{34}$ the

27. In Regents of University of California v. Bakke, 438 U .S. 265 (1978), four justices held that the Constitution forbids making race-based admissions decisions for affirmative action, four justices held that the Constitution imposes no such limits, and J ustice Powell, joined in part by the first four and in part by the other four, held that the Constitution does not allow racial quotas in voluntary affirmative action programs but does allow affirmative action programs that consider race as one of several factors. See id. at 280-81 n.14 (discussing the basis for Bakke's standing to challenge the race-based admission policy at the U niversity of California M edical School at D avis).

28. For post-Bakke opinions denying standing to a white challenger of a preferential admissions program, see D oherty v. R utgers Sch. of L aw, 651 F.2d 893 (3d Cir. 1981) and D iL eo v. Board of Regents of Univ. of Colo., 590 P.2d 486 (Colo. 1978), cert. denied, 441 U .S. 927 (1979). O pinions prior to Baake include D onnelly v. Boston College, 558 F.2d 634 (1st Cir. 1977), cert. denied, 434 U.S. 987 (1977) and Henson v. University of A rk., 519 F .2d 576 (8th Cir. 1975).

29. See, e.g., A dams v. Richardson, 480 F.2d 1159 (D.C. Cir. 1973) (demanding integration of higher education systems in southern states with no showing that named plaintiffs would have met the admissions requirements of previously white institutions).

30. N ortheast Fla. Chapter of the A ssociated G en. Contractors of A m. v. City of J acksonville, 508 U.S. 656 (1993). The opinion notes that a coalition of public interest advocacy groups had submitted an amicus brief urging the Court to refuse standing and treat the standing of $A$ llen $B$ akke as based on legal reasoning no longer valid. See id. at 665 (citing B rief for Public Citizen et al. as A mici Curiae at 7, N ortheast Fla. Chapter of the A ssociated G en. Contractors of A m. v. City of J acksonville, 508 U.S. 656 (1993) (N o. 91-1721)).

31. See N ortheast Fla. Chapter of the A ssociated G en. Contractors of A m. v. City of J acksonville, 951 F.2d 1217 (11th Cir. 1992), rev'd, 508 U .S. 656 (1993).

32. 515 U .S. 200 (1995).

33. Id. at 227.

34. 490 U .S. 755 (1989). 
Supreme Court rejected this practice, insisting that a consent decree could only bind the immediate parties-and not exclude nonparties from subsequently challenging its legality. The case was decided by $5-4$, and the J ustices split on this procedural point almost exactly as they had on the merits of previous cases about racial preferences. ${ }^{35}$ The reason is obvious. If constitutional and statutory bans on discrimination are conceived as conferring a special kind of environmental entitlement to particular "protected" groups, there must be restrictions on court challenges by the less favored groups. It is hard to maintain an environmental entitlement if anyone can challenge its terms.

The shift in procedure may be part of the reason why class action employment discrimination cases- seeking class-wide remedies like hiring and promotion quotas-have declined quite markedly since the $1970 \mathrm{~s}^{36} \mathrm{E}$ mployers cannot be expected to negotiate a class-wide settlement of a discrimination case if that very settlement can subsequently be challenged by third parties and become unsettled again. A series of Supreme Court decisions in the 1980s also cut back on the availability of attorneys' fees, making it easier for named plaintiffs to accept a settlement with no provision for fees. ${ }^{37}$ At the same time, the Court began to impose other procedural restrictions on class certification. ${ }^{38} \mathrm{~A} I I$ these trends seem to have a similar root-doubt that attorneys are actually benefiting "the public" when they demand relief for a broad, amorphous constituency.

The result, according to a recent survey of civil rights attorneys, is that discrimination cases have come to look more like personal injury tort claims in the way they are handled by attorneys. ${ }^{39}$ In other words, "civil rights" cases look more like individualized claims to a certain standard of treatment by employers. By the same token, they look less like an environmental entitlement to a racially balanced workforce. The decline in claims to environmental entitlements has meant a lesser role for the private attorney general.

35. Samuel Issacharoff notes that J ustices Blackmun, M arshall, Brennan (three of the four dissenters) had voted in favor of affirmative action in all seven cases raising the issue before the Court in the years preceding 1988, while R ehnquist, the author of the majority opinion, had voted against affirmative action in all seven cases. When Substance $M$ andates Procedure, $M$ artin v. Wilks and the Rights of Vested Incumbents in Civil Rights Consent Decrees, 77 CORNELL L. REV. 189, 205 n.74 (1992). A part from J ustice Stevens (who joined the dissenters, despite have taken different positions in other cases), the others had not been on the Court long enough to vote on all seven of these cases, but their votes generally tracked their positions in Wilks.

36. See J ohn J. D onohue \& Peter Siegelman, The Changing $N$ ature of E mployment Discrimination L itigation, 43 STA N. L. REV. 983 (1991).

37. See Evans v. Jeff D., 475 U.S. 717 (1986); see also Farrar v. Hobby, 506 U.S. 103 (1992) (holding that nominal damage award does not qualify attorney to claim fees as "prevailing" party); R hodes v. Stewart, 488 U.S. 1 (1988) (same for declaratory judgement).

38. See D avid Shulb, Private A ttorneys G eneral, Prevailing Parties and Public B enefit: A ttorney's Fees A wards for Civil Rights Plaintiffs, 1992 D UKE L.J . 706; B ryant Garth et al., The Institution of the Private A ttorney G eneral: Perspectives from an E mpirical Study of Class A ction L itigation, $61 \mathrm{~S}$. CAL. L.REV. 353 (1988).

39. See J ulie Davies, Federal Civil Rights Practice in the 1990s: The Dichotomy Between Reality and Theory, 48 H A STINGS L .J . 197 (1997). 
IV

\section{ENVIRONMENTA L ENTITLEMENTSAND THE CHANGE IN ENVIRONMENTA L PROTECTION ENFORCEMENT}

Citizen suits, authorized under the environmental protection legislation of the 1970s, exemplify the private attorney general at work. The power to enforce a new environmental protection policy standard would seem to be the most dramatic instance of an environmental entitlement. In practice, however, it is very difficult to discern what steps- what precise commands to what precise actors - will achieve a particular desired level of pollution reduction. So the environmental entitlement here is not so much a claim to a certain outcome as a license to litigate on behalf of that outcome. A nd, just as in other areas, the litigating license here has not been conferred in a random or unpredictable way. It has been conferred on particular constituencies who become, so to speak, the holders of the entitlement.

Under the Clean Water A ct, for example, "any citizen" may bring suit against a source of water pollution. ${ }^{40}$ In principle, this language allows anyone at all to bring a suit. In reality, however, the plaintiff receives no direct financial reward for bringing a citizen suit under the Clean W ater A ct; hence, virtually no ordinary citizen can afford to bring a private lawsuit to improve the water quality of his town or county simply as a public service. Business firms may have more direct incentives to bring such cases, but courts have denied standing to business firms seeking to have environmental sanctions imposed on commercial rivals with a poor environmental record: The business plaintiff does not have standing because the claim asserted is not within the "zone of interests" which the statute sought to protect. ${ }^{41}$ It is probably equally accurate to say that the plaintiffs in such cases did not have the "right motives." In fact, the Supreme Court has held that statutes conferring citizen standing preempt traditional common law remedies- where the plaintiff necessarily sues on behalf of his own private interest. ${ }^{42} \mathrm{U}$ ntil recently, the converse also applied: Courts were quite ready to authorize suits against polluters by public interest plaintiffs who could show a violation of the statute- even if they could not show that the violation had actually harmed water quality, let alone harmed any clear or direct interest of the plaintiff. Thus many filings over the past two decades involved charges that a particular firm has failed to file the discharge notification statements required under the statute. ${ }^{43}$ Indeed, the extensive record-keeping

40. 33 U.S.C. $\S 1365($ a) (1994) ("[A ]ny citizen may commence a civil action on his own behalf(1) against any person ... who is alleged to be in violation of (A) any effluent standard or limitation under this chapter or (B) an order issued by the A dministrator [of the EPA ] or a State with respect to such a standard or limitation ...").

41. See, e.g., H arzardous Waste Treatment Council v. Thomas, 885 F.2d 918 (D.C. Cir. 1989); H azardous W aste Treatment Council v. E PA, 861 F.2d 277 (D.C. Cir. 1988).

42. See M iddlesex County Sewerage A uth. v. National Sea Clammers A ss'n, 453 U .S. 1 (1981).

43. See Barry Boyer \& Errol M eidinger, Privatizing Regulatory E nforcement: A Preliminary Assessment of Citizen Suits U nder Federal E nvironmental L aws, 34 B U FF. L. R EV . 833, 917-18 (1985). 
required by the Clean $W$ ater $A$ ct seems to account for the concentration of private enforcement actions under this particular statute. ${ }^{44}$

The kinds of violations most easily "caught" by private advocacy groups are statutory "violations" which the EPA has already learned about-and the advocacy groups then learn of them from EPA's own records. Since the Clean Water Act requires that the EPA be allowed to pursue cases on its own authority, the cases left to private enforcement are those where the EPA declines to take action. The usual reason, it seems, is not that EPA lacks enforcement resources for these cases, but that they are too minor or technical to be worth pursuing. ${ }^{45}$ Such violations have been quite worthwhile for environmental advocacy groups to pursue, however. If firms must pay all fines to the federal Treasury, both the firm and the plaintiff advocacy group have an incentive to reach an out-of-court settlement so long as the cost of the settlement is less than the full cost of paying the fine. Thus, a widespread practice arose in the 1980s of negotiating settlements in which firms agreed to devote funds to environmental improvements, while the plaintiff agreed not to pursue the suit toward final judgment (and the ensuing payment of a full fine to the Treasury). The firms then make the payments not directly to the particular litigating organization but to some environmental project in the area- often one conducted by a sympathetic local or allied advocacy group. The firm has no incentive to be fussy about recipients (so long as the total cost is less than the potential fine), nor does the plaintiff have much incentive to focus the relief on the precise injury (supposing there was one) that provoked the lawsuit.

$M$ ichael $G$ reve documented the extent of this pattern during the $1980 s^{46}$ and concluded that the pattern of incentives did not contribute to a sensible enforcement program. From a public perspective, private actions would be most beneficial if they focused on pollution sources not already known to the government. But these are most expensive and difficult to find. The incentive of the private attorney general under the current system is instead to focus on those pollution sources which have already been identified in government filings, which are thus cheapest and easiest to proceed against in a lawsuit. $Y$ et such actions need not produce a result that corresponds in any way to public enforcement priorities. G reve concluded that the skewed incentives persist because the system provides an off-budget source of contributions to the environmental advocacy movement. ${ }^{47}$

The incentive structure may not be so skewed when it comes to citizen suits to force the government itself to take action. But it remains true that what galvanizes environmental advocates may not accord with the most appropriate priorities from a public standpoint. There is still an incentive to bring suit when

\footnotetext{
44. Seeid. (1990).

45. See M ichael S. G reve, The Private Enforcement of Environmental L aw, 65 TUL. L. REV. 339

46. Seeid.

47. Seeid. at 390 .
} 
the case is easiest to win rather than where enforcement deficiencies are responsible for the most pollution. For example, environmental advocacy groups have long insisted on litigating failures to meet statutory deadlines for pollution reduction under the $\mathrm{Clean} \mathrm{A}$ ir $\mathrm{A}$ ct, even when everyone recognizes that the actual deadline is impossible to meet, even with court-ordered prompting. ${ }^{48}$ on the other hand, ideological imperatives may drive environmental advocates to take positions which most policy analysts do not endorse, but which make some sense in the larger political calculations of environmental advocates. In air pollution litigation, environmental advocates strenuously opposed E PA efforts to let polluting firms trade off polluting emissions from their own firms against greater reductions from other firms. E conomists were convinced (and rightly, as subsequent experience confirmed) ${ }^{49}$ that such policies promised equivalent or greater reductions in air pollution at less cost than the application of inflexible limits for each pollution point-source. But this approach was based on a cost/benefit analysis to which environmentalists were quite opposed, for fear that it would weaken rhetorical or political commitments to seeing pollution as a moral evil.

It is likely that judicial solicitude for environmental advocacy groups depended on an underlying perception that environmentalists were the "good guys" in policy disputes of the 1970s. There since has been a notable (though gradual) shift in the judicial posture toward environmental protection litigation. It has expressed itself in the introduction of new impediments to litigation by "private attorneys general."

In Chevron v. NRDC, ${ }^{50}$ the Supreme Court insisted that agency interpretations of the relevant statute should be given deference by courts, even when challenged by environmental advocates seeking more rigorous enforcement. The ruling rests on the fundamental premise that legal interpretation is partly a matter of policy, and that policy matters should be the primary responsibility of government officials. The latter are accountable to the electorate and no advocacy group- even one that styles itself a public interest group-can be accountable in this way.

The most revealing change has been in the doctrine of standing. The Court had already begun to emphasize in the mid-1970s that A rticle III set fundamental limitations on the sorts of claims that could be heard by federal courts. Standing, it was said, required some showing of a "concrete injury." A series of standing cases developed two additional, though related requirements: that the injury must be fairly traceable to the challenged action, and that the relief

48. See R. Shep M elnick, Pollution Deadlines and the Coalition for Failure, 75 PUB. I NTEREST 123, 131-32 (1984).

49. See R obert W. Hahn \& Gordon Hester, Where Did All the Markets Go?, 6 Y ALE J. ON REG. 109,110 (1989).

50. 467 U.S. 837 (1984). O ne observer who saluted this ruling as a "watershed" in administrative law for its call to respect executive authority was Kenneth Starr. See Kenneth W. Starr, J udicial Review in the Post-Chevron E ra, 3 Y A LE J . ON REG. 283 (1986). 
sought must be likely to provide actual alleviation of the underlying injury. ${ }^{51}$ The requirements were articulated in cases rejecting policy-oriented suits by public interest advocacy groups. In every one of these cases, advocacy groups-or "private attorneys general" - were resorting to courts to demand more extensive government controls. It remained unclear for some time whether the new doctrine would be applied in a rigorous way to environmental statutes.

In its 1992 ruling in L ujan v. D efenders of Wildlife, ${ }^{52}$ the Supreme Court emphasized that it would indeed apply the new standing requirements to environmental protection litigation. In that case, the Court denied standing to an environmental advocacy group challenging federal grants for the construction of a new dam. The challengers claimed that the dam would have threatened species which they had viewed on previous trips to the area and might wish to see again in the future. ${ }^{53}$ B ut the dam was being built in E gypt and most of the funding for it did not come from the U.S. government. ${ }^{54}$ The Court accordingly ruled that the potential for relief was far too speculative, since the dam might be built in any case. ${ }^{55}$ Standing, the Court insisted, requires a showing of "injury in fact," which it defined as the invasion of a legally protected interest that is "(a) concrete and particularized, and (b) actual or imminent, not 'conjectural' or 'hypothetical.'" 56

The decision received a good deal of critical attention from commentators. ${ }^{57}$ Some scholars argued that Congress could assure standing to environmental protection plaintiffs in future cases simply by providing a "bounty" for successful litigation, thereby giving litigants the necessary assurance of a "personal stake in the outcome." Wh Whatever the merits of this proposal as a matter of constitutional doctrine, it is notable that Congress did not display any interest in pursuing it. On the contrary, Congress subsequently went to considerable trouble to cut back on somewhat analogous private attorney general litigation under the Securities A ct. ${ }^{59}$

51. See Simon v. E astern Ky. Welfare Rights O rg., 426 U .S. 26 (1976) (rejecting standing for an effort to force the IRS to impose free care provisions on non-profit hospitals); W arth v. Seldin, 422 U.S. 490 (1975) (rejecting standing in a case seeking to invoke a supposed new constitutional requirement that local zoning codes not include any provision that would even indirectly reduce racial integration in residential patterns); L inda R.S. v. Richard D ., 410 U.S. 614 (1973) (rejecting standing for an effort to require criminal prosecutions of fathers failing to pay child support).

52. 504 U .S. 555 (1992).

53. See id. at 562-64.

54. Seeid. at 571.

55. Seeid.

56. Id. at 560 (citations omitted) (quoting Whitmore v. A rkansas, 495 U.S. 149, 155 (1990) (quoting City of L os A ngeles v. L yons, 461 U.S. 95, 102 (1983))).

57. See, e.g., Cass R . Sunstein, What's Standing A fter L ujan? supra note 7.

58. Id. at 233.

59. See Private Securities Litigation R eform A ct of 1995, Pub. L. No. 104-67, 109 Stat. 737 (codified in scattered sections of 15 U.S.C. (Supp. I 1995-96)). The PSLRA was enacted by Congress after overriding President Clinton's veto. 
The Court did not respond to the criticism with a more cautious approach. The 1998 decision in Chicago Steel and Pickling Company v. Citizens for a B etter $E$ nvironment ${ }^{60}$ reemphasized the logic of $L$ ujan by rejecting standing for an environmental group which sought to enforce the Clean Water A ct reporting requirement. The problem was that the group offered no evidence that improperly reported discharges had actually increased pollution. If there were no increase in pollution, the Court held, there could be no injury, and hence no standing.

A the same time that it restricted standing for environmental advocates, the Supreme Court took a more receptive view of standing for regulated interests. Thus, only one year before it limited standing in Chicago Steel, the Court insisted in B ennett v. Spear ${ }^{61}$ that ranchers must be given standing to challenge a decision of the Interior D epartment classifying a new habitat under the E ndangered Species A ct, because that decision would have had seriously adverse consequences for the ranchers. O nly on the surface are the opinions contradictory. Both were written by Justice Scalia. Chicago Pickling rejected the idea that being within the vague "zone of interests" could overcome the lack of an actual injury. B ennett, on the other hand, rejected the government's argument that standing should be denied because the plaintiffs' economic injuries were not within the "zone of interests" which the statute sought to protect: J ustice Scalia acknowledged that the statute was meant to "favor" environmentalists but denied that it should be construed in the one-sided way the government urged. Both opinions reflect an effort to reorient the judicial role from the enforcement of environmental entitlements toward the traditional role of protecting individualized private rights.

These are not straws in the wind. L ower court decisions confirm a similar pattern. ${ }^{62}$ The question is how far it will go. There are reasons to doubt that it will go as far as the logic of the $L$ ujan opinion might suggest. B ut before returning to these reasons, it may be useful to step back and look at the status or role of the "private attorney general" in a wider context.

\section{$\mathrm{V}$ \\ I NCENTIVES, JUDGMENTS, AND JUDGMENT}

L awsuits brought by specialized, issue-oriented public interest organizations are by no means the only setting in which the term "private attorney general" is invoked. A nyone can call himself a "private attorney general"-or a "public citizen," for that matter. It is revealing that there is still no legal definition, nor

60. 118 S. Ct. 1003 (1998).

61. 520 U .S. 154 (1997).

62. See Public Interest R esearch G roup, Inc. v. Magnesium Elktron, Inc., 123 F.3d 111 (3d Cir. 1997) (holding actual violations of Clean W ater A ct by M agnesium Elecktron not sufficient to confer standing on Public Interest R esearch Group without showing of actual harm); Friends of the Earth, Inc. v. Crown Cent. Petrol. Corp., 95 F.3d 358 (5th Cir. 1996); O gden Projects, Inc. v. New M organ L andfill Co., Inc., 911 F. Supp. 863 (E.D.Pa. 1996). 
any well-established pattern of usage, which precisely identifies a litigant as a "private attorney general." The term is not simply reserved for the efforts of non-profit advocacy organizations. B ut the private attorney general has been treated with increasing skepticism and caution, even where the term is deployed by "mercenary" advocates, who seek to profit quite directly by advocacy on behalf of the public. It is not so much the ideological profile of the private attorney general that has brought it disfavor as the notion that unelected advocates can speak for the public-whatever their motives.

If the term is defined simply as one who brings a lawsuit that may benefit third parties, then indeed almost any litigant might qualify. A ny lawsuit might clarify or reinforce a principle of law that benefits others down the road. At this level of abstraction, M r. Chadha, whose lawsuit resulted in the invalidation of the congressional veto procedure, might well be regarded as a private attorney general. So might Paula J ones, who triggered a whole series of political earthquakes with her sexual harassment suit against President Clinton. A nd both Chadha and Jones, in fact, relied on pro bono assistance from law firms which were not simply undertaking charitable assistance to distressed individuals. $^{63}$ O nce one views the lawsuit through the prism of the larger issue at stake, however, not everyone will see the lawsuit as a public benefaction. Those who disagree with the political agenda of the lawyers will not be pleased to see them advance it through litigation. The lawyers can say they are performing a public service, but others will see their role as partisan.

We might get closer to the core of the concept by identifying the "private attorney general" with the lawsuits that the law itself particularly encourages. The most common device for encouraging lawsuits is to shift the usual "A merican rule" on fees so that a party with a meritorious lawsuit can recover legal fees. A great many contemporary cases therefore invoke the term "private attorney general" in the context of a dispute about whether the prevailing party should receive attorneys fees. Fee disputes do capture some of the inherent ambiguity in the concept.

If it is a service to the public to bring a case about civil rights, why is it not also a service to defend such a case when the plaintiff is overreaching? Where the civil rights claim does not reach, after all, the defendant is free to use his liberty or property as he sees fit-and liberty and property, come to think of it, are also fundamental rights. For discrimination claims under the Civil Rights A ct of 1964, however, the Supreme Court held that attorneys' fees cannot be claimed by a prevailing defendant, since this would discourage prospective plaintiffs. $^{64}$ In recent decades, the Court has narrowed and confined this treat-

63. Jagdish $\mathrm{R}$ ai Chada, an immigrant of limited means, was represented throughout his years of litigation by A lan M orrison, chief litigator for Ralph Nader's (left-of-center) advocacy organization, Public Citizen. Paula J ones was assisted by the (right-of-center) advocacy organization, the R utherford Institute.

64. In Christiansburg Garment Co. v. E E O C, 434 U.S. 412 (1978), the Court insisted that only the plaintiff should receive attorneys' fees under the statutory provision in Title VII of the 1964 Civil Rights A ct, allowing fees for the "prevailing party." The Court gave the opposite interpretation to 
ment. It has refused to disallow claims by other prevailing defendants, where statutes do provide for fee shifting. A t the same time, the Court has insisted that fees must be limited to fully prevailing parties in litigation-so that advocacy lawyers cannot collect compensation for winning moral victories or partial victories or rulings that result in minimal financial recompense to the plaintiff. ${ }^{65}$ In general, the Court's stance toward attorneys' fees has operated as a curb on would-be private attorneys general, reducing them to the status of private parties pursuing litigation for their own ends and at their own risk.

D isputes about attorneys' fees, however, are probably a secondary matter, both in theory and practice. The cost of litigation is certainly a great hurdle for many would-be litigants. E ven provisions for attorneys' fees, however, do not go very far in surmounting this burden, since fees come-if at all-only after years of legal fencing, so that the party (or the attorney) must be prepared to make a long-term investment. Not many attorneys, it seems, are prepared to do so for non-paying clients.

To the extent that economics drives the decision to act as a private attorney general, more is needed than the promise of fees far down the road. The need for more powerful or reliable incentives is recognized in two legal arrangements where the term "private attorney general" is sometimes deployed. First, and most common, are provisions for punitive damage awards. The theory behind punitive damages is that particularly willful or reckless tortfeasors ought to suffer some penalty, beyond merely paying for the damage they have caused. The deterrent effect, however, does not require that the penalty be paid to the plaintiff. ${ }^{66}$ The point of allowing the plaintiff to recover punitive damages (or treble damages in certain federal statutes) ${ }^{67}$ is to encourage lawsuits beneficial to the public.

It is notable, however, that this practice has provoked much controversy in the past two decades. Some critics have emphasized the tendency of juries to award startlingly large punitive damage claims when local plaintiffs go after

similar language in the Copyright A ct-allowing "prevailing" defendants to recover fees and not just "prevailing" plaintiffs- and the concurring opinion by J ustice Thomas in that decision emphasized that the discrepancy in the civil rights context would no longer be tenable if it were not so long established. See Fogerty v. Fantasy, Inc., 510 U .S. 517, 538 (1994).

65. See D avid Shub, Private A ttorneys G eneral, Prevailing Parties and Public B enefits: Fee A wards for Civil Rights Plaintiffs, 1992 D UKE L.J. 706, 713.

66. In fact, a number of states do not allow punitive damages simply to revert to the plaintiff. Florida, for example, makes $35 \%$ of such damages payable to a special state fund. See FLA. STAT. A NN. $\$ 768.73(2)(a)$ (b) (West 1997). I owa directs that fully $75 \%$ of punitive damage awards should go to a civil reparations trust fund. See I OWA CODE A NN. § 668A.1(2)(b) (W est 1998). But only a minority of states have adopted this practice and it is not the practice in federal litigation.

67. See Clayton A ntitrust A ct, 15 U .S.C. § 15(a) (1994). B ut the Supreme Court has emphasized that to recover damages, the plaintiff must not only show injury but also show that the defendant's action had the overall effect of reducing competition. See A tlantic R ichfield Co. v. U SA Petroleum Co., 495 U.S. 328, 343 (1990). A nd some commentators have urged further reductions in competitor standing in this area. See, e.g., E dward A. Snyder $\&$ Thomas L. K auper, M isuse of the A ntitrust L aws: The Competitor Plaintiff, 90 M ICH. L. REV . 551 (1991). 
out-of-state corporations. ${ }^{68}$ In response to such abuses, the Supreme Court insisted that the Constitution requires that punitive damages (even when awarded by state courts) must bear some reasonable relation to actual damages. $^{69}$ The Court developed this novel constitutional theory, ${ }^{70}$ to reduce the private attorney general aspect of punitive damage claims and to reemphasize the actual injury to the actual plaintiff. E ven so, many critics warn that punitive damages encourage speculative litigation by aggressive trial lawyers operating on contingency fees. When the plaintiff bears no cost and a trial lawyer can finance several unsuccessful efforts with one immense punitive damage award, the lawyer can sift through cases like a commercial investor. Congress has repeatedly considered wider reforms to limit such litigation and many states have al ready imposed their own caps on damage awards and punitive damage claims. The least one can say in the meantime is that there is no longer any general consensus that encouraging aggressive litigation (even where there are undoubted personal injuries) is an unequivocal contribution to public welfare.

The second, seemingly more focused incentive scheme is the federal law which allows anyone to bring a qui tam action to uncover fraud by federal contractors. The practice has roots in English common law and has been adopted at various times since the eighteenth century. The modern version is the False Claims A ct of $1986,{ }^{71}$ which covers claims against contractors doing business with the federal government. In this scheme, private parties may bring lawsuits to challenge contractors who have made misrepresentations that defraud the federal government. The incentive to do so is that successful claimants are given a portion of the resulting fines.

This practice, too, has become controversial because the incentives are hard to match to the needs of sensible law enforcement. A great many cases are brought by disgruntled employees or others with scores to settle, and sometimes the suits are brought as bargaining tactics in organized labor disputes. ${ }^{72}$ There is an obvious explanation for this pattern. B efore one can be a private attorney general in this setting, one needs to be a private detective to uncover false reports by the company involved. That is quite expensive and difficult,

68. See, e.g., Victor E. Schwartz \& M ark A. Behrens, Punitive Damages Reform-State L egislatures $C$ an and Should M eet the Challenge I ssued by the Supreme Court of U nited States in Haslip, 42 A M. U . L. R EV. 1365 (1993); D an Q uayle, Civil J ustice Reform, 41 A M. U. L. R EV. 559 (1992).

69. See BM W of N. A m., Inc. v. Gore, 517 U .S. 559, 580 (1996). A n amicus brief from the A labama Trial A ttorneys argued, characteristically, that it would be better to have "insurance bad faith and fraud and garden variety consumer fraud policed primarily by private attorneys general through the civil jury system, rather than by government bureaucracies." B rief for A la. Trial L awyers A ss' $n$ as A micus Curiae in Support of R espondent at 7, B M W of N. A m., Inc. v. Gore, 517 U .S. 559, 580 (1995) (No. 94-896). The Supreme Court was not persuaded that this benefit required punitive damages to exceed actual damages by a factor of ten.

70. Only a few years earlier, the Supreme Court had unanimously rejected the argument that punitive damages are tantamount to "fines" which should accordingly be regulated by the Eighth A mendment prohibition on excessive fines. See Browning-Ferris Indus. v. Kelco Disposal Inc., 492 U.S. 257, 260 (1989).

71. 31 U .S.C. §§ 3729-33 (1994).

72. See R obert E. J ohnson, N ote, 1001 A ttorneys $G$ eneral: Executive-E mployee $Q$ ui Tam Suits and the Constitution, 62 G E O. W A SH. L. REV . 609 (1994). 
unless one already has access to company records as an insider. B ut contented employees are not eager to risk their positions by bringing speculative lawsuits. So the law attracts those with a special grudge-a private grudge.

In the background is a serious issue: Why should it be up to a private party to decide when a legal violation is serious enough to justify a prosecution? The statute gives the public A ttorney $\mathrm{G}$ eneral some control over the matter, by requiring qui tam plaintiffs to notify the J ustice D epartment, which then can decide to join in the case or order it halted. B ut the law does not require the J ustice D epartment to make either decision, and it actually imposes a series of procedural hurdles that may discourage the government from halting the case. $M$ any cases thus go forward without any participation by the J ustice Department, which neither affirms nor denies the claim. R esponsibility is shifted from the A ttorney $\mathrm{G}$ eneral to the private party-whose motives are not under scrutiny. O ne federal district court recently declared the statute unconstitutional. ${ }^{73}$ A $n$ appeals court insisted that claims should be dismissed if not actually endorsed by the A ttorney $\mathrm{G}$ eneral. ${ }^{74}$

There has, in fact, been a sizable body of literature on the constitutional status of qui tam actions. ${ }^{75}$ If it seems disproportionate to the policy effects of the statute, that is no doubt because many of the those writing on the subject see the qui tam action as a test case for a wider reliance on private attorneys general. If the qui tam plaintiff can act without claiming any injury of his own, surely a public interest organization should be able to act when it claims a somewhat speculative injury-but an injury nonetheless- to its own concerns. The qui tam plaintiff, however, is suing on behalf of the government. Courts which have upheld the False Claims A ct against constitutional challenge have done so on the theory that the government itself is the real party in interest, bearing the real injury. ${ }^{76}$ This theory, even if it satisfies most courts in dealing with a qui tam plaintiff, cannot explain suits where unconventional plaintiffs seek redress against the government itself. Nor, of course, does the False Claims A ct or any other statute provide comparable financial incentives to sue the government. Congress has been quite unwilling to waive sovereign immunity for anything like a qui tam action against federal agencies. Where there is no prospect of sizable awards (or some other, indirect economic reward to the plaintiff), only non-profit legal organizations are likely to press a case. Since

73. See U nited States ex rel. R iley v. St. Luke's E piscopal Hosp., 982 F. Supp. 1261, 1269 (S.D. Tex. 1997).

74. See U nited States ex rel. Berge v. Board of Trustees of the U niv. of A la., 104 F.3d 1453 (4th Cir. 1997).

75. See, e.g., James T. Blanch et al., Citizen Suits and Qui Tam Actions: Private ENFOR CEMENT OF PUBLIC POLICY (Roger Clegg $\&$ James L.J. Nuzzo eds., 1996); A ra Lovitt, Note, Fight for Your Right to L itigate: Q ui Tam, A rticle II and the President, 49 STA N. L. REV. 853 (1997); J ames T. B lanch, N ote, The Constitutionality of the False Claims A ct's Q uit Tam Provision, 16 H A RV. J.L. \& PUB.POL'Y 701 (1993); Evan Caminkert, Comment, The Constitutionality of Qui Tam A ctions, 99 Y A LE L.J. 341 (1989).

76. See Berge, 104 F.3d at 1457; U nited States ex. rel. Killingsworth v. Northrop Corp., 25 F.3d 715, 720 (9th Cir. 1994); U nited States ex rel. K reindler \& K reindler v. U nited Technologies Corp., 985 F.2d 1148, 1154 (2d Cir. 1993). 
their funding does not come from the client, they have no great incentive to worry about exactly what the client may prefer, if there even is a separate client. In that sense, the public interest law firm litigating in its own name may seem to fulfill the ultimate logic of the private attorney general, because it is most removed from the immediate interest of any particular party or rights holder.

Litigation remains costly, however, even if funded by a tax-exempt organization. This may be part of the reason why, when courts were most sympathetic to public interest advocacy, they were inclined to establish a regime in which the public interest advocates had a favored position. A s a practical matter, moreover, it is hard to establish an effective scheme of enforcing environmental entitlements when the targets of such enforcement are pushed and pulled from opposing directions. Perhaps the half-conscious thought was that policing that is not done by government needs to be done by organizations which have something like the privileged (and exclusive) authority of government. A t any rate, courts have in the past decade shown increasing reluctance to continue such a privileged status for public interest organizations.

\section{VI}

\section{CONCLUSION: WHOM TO DISTRUST?}

The doctrine of $L$ ujan suggests that the standing of public interest organizations could be questioned even in the common situation where such organizations challenge new regulations as insufficiently rigorous or protective. If standing is denied when the government funds a dam in E gypt, why not when it issues a new regulation in Washington that some advocates regard as insufficiently rigorous or protective? When the E nvironmental D efense Fund challenges a new EPA regulation or when $\mathrm{R}$ alph Nader's Public Citizen challenges a new OSH A standard, the harm to any particular person is necessarily remote and speculative. M any intervening factors, after all, may prevent the ultimate harm that advocates fear, and one can never be sure whether actual members of these organizations will actually be injured, even if there is a measurable worsening in air quality or increase in work-related illness.

There has been no sign, however, that courts are prepared to challenge standing where statutes provide for pre-enforcement review of new regulations. ${ }^{77}$ This is ironic. The Supreme Court itself has insisted that standing doc-

77. See, e.g., Sierra Club v. EPA, 118 F.3d 1324 (9th Cir. 1997) (challenging EPA import permit rule on hazardous wastes, with importing companies as respondent intervenors); A merican Iron \& Steel Inst. v. EPA, 115 F.3d 979 (D.C. Cir. 1996) (challenging new EPA guidelines on Trial Water Quality Guidance for Great Lakes System with National Wildlife Federation as intervenorrespondent); E nvironmental D efense Fund, Inc. v. EPA, 82 F.3d 451 (D.C. Cir. 1996) (challenging new EPA regulations under the $C$ lean $A$ ir $A$ ct by the E nvironmental D efense Fund, joined by Sierra Club, $N$ atural Resources Defense Council, and other environmental advocacy groups, and opposed by A merican Trucking A ssociation and A merican $\mathrm{R}$ oad and Transport B uilders A ssociation). In O il, Chemical \& A tomic Workers Union v. OSH A, 145 F.3d 120 (3d Cir. 1998), Public Citizen joined with the union as co-plaintiff and no questions about standing were raised, although the court did reject the 
trine is supposed to exclude ideological plaintiffs who pursue a cause without a personal injury. Y et where public interest organizations are making the most purely ideological claims-because actual consequences are most speculative and remote- they have been quite secure in their access to the courts.

There is, however, an obvious difference when the setting is a challenge to a new regulation in pre-enforcement review. Opposing interests, such as business firms complaining that the regulation is too onerous, typically have already received statutory leave to pursue such challenges, and various contending interests typically do participate. The public interest organization challenge may look acceptable to courts in this setting precisely because it is seen as a champion of one side in the context of competing interest groups. In other words, the ideological plaintiff is acceptable to courts when not seen as a surrogate for government enforcement, but simply as an interest advocate in a lawsuit that is itself a surrogate for a legislative or political process.

Still, the standing of public interest organizations remains incongruous as a matter of formal doctrine. Why do courts not resolve this anomaly with a clearer or cleaner doctrine? It is clear why courts do not proclaim such lawsuits "public actions" and waive all standing requirements: If the "case" is not about alleviating injury to a particular plaintiff, then the case can only be about enforcing the judicial view of how the law should be interpreted. Indeed, where there are no personal rights at stake, the case will turn on little more than the judicial view of how the government or the country should be run. A n opinion in such a "case," then, would be the most naked exercise of judicial power. This may have seemed acceptable in the 1960s, when there was greater consensus-at least among elites-about the "right" positions. By the late 1970s, however, it was no longer so clear which policies courts could adopt on their own, without fear of protest and reproach.

$\mathrm{N}$ or is it very satisfactory to go the opposite route and simply affirm that anxiety about future harm is, in itself, always enough "injury" to satisfy the requirements of standing. Once it is acknowledged that non-material injuries may be considered (such as the affront some people feel at government entanglement with religion, or the distress others feel at depredations of the natural environment), then almost anything might be conceived as an "injury." The Court seems concerned to assure that access to the courts is not opened so wide that there is no real chance to work out local or political compromises between contending political forces. $^{78}$ If anything at all can be invoked as sufficient

motion (not opposed by industry groups) to force OSHA to set a schedule for the issuance of a new protective regulation on hexavalent chromium.

78. Even in relation to the Establishment Clause, the Court seems to be backing away from its past reasoning. In L ee v. Weisman, 505 U.S. 577 (1992), the Court found a violation of the Establishment Clause in a brief, non-sectarian prayer offered by a rabbi at a high school graduation ceremony. A ccording to J ustice K ennedy's majority opinion:

The injury caused by the government's action ... is that the State, in a school setting, in effect required participation in a religious exercise. It is, we concede, a brief exercise during which the individual can ... let her mind wander. But the embarrassment and the intrusion of the 
"injury" to go to court, then one side may be continually in court-or everyone will be-and courts will again be supervising all details of policy in contentious policy fields.

The logic of J ustice Scalia's articulation of standing requirements in L ujan may go beyond what the Court can actually insist upon because it goes beyond what Congress can accept. If standing is a constitutional requirement, grounded in the separation of powers, then there must be sharp limits on the power of Congress to transfer executive authority to private attorneys general. ${ }^{79}$ V ery similar reasoning-safeguarding the separation of powers from congressional tampering-would suggest that the executive power cannot even be parceled out to autonomous public officials, anymore than to private litigants. A nd that is, of course, exactly the argument advanced by J ustice Scalia in M orrison v. OIson, ${ }^{80}$ where he argued that the establishment of Independent Counsels in the $E$ thics $A$ ct is an unconstitutional intrusion on executive authority.

If this logic were ever fully endorsed by the Supreme Court, there might seem to be no constitutional procedure to remedy suspected criminality in the executive. B ut there is, of course, always a constitutional remedy of last resort: impeachment. Preparatory to impeachment proceedings, Congress can launch intensive investigations on its own. It can subpoena files and records (and even recordings) from the $\mathrm{W}$ hite $\mathrm{H}$ ouse and, as the Nixon impeachment experience suggests, it can even impeach a President for refusing to honor such subpoenas. Before that, Congress can demand that an A ttorney General appoint an independent investigator and hold the A ttorney General to this promise, even in the absence of a formal statute creating an independent office.

But all such measures require Congress to take an openly adversary stance, which defenders of the President will often decry as "partisan." The statute creating the Independent Counsel is designed to spare Congress the burden of appearing "partisan" or "political" when it demands that presidential misdeeds be fully investigated. The statute, in other words, transforms a political interest

religious exercise cannot be refuted by arguing that these prayers... are of a de minimis character.

Id. at 594. J ustice Scalia's dissent mocks the Court's "psycho-journey" for "expanding the concept of coercion beyond acts backed by threat of penalty-a brand of coercion that, happily, is more readily discernible to those of us who have made a career of reading the disciples of B lackstone rather than of Freud." Id. at 643. But it is notable that the majority opinion opens itself to such ridicule because it insists on finding something like "coercion" at the bottom of the "injury" here, rather than simply reaffirming past holdings that Establishment Clause challenges do not require a showing of "coercion." The compulsion to find "coercion" at the bottom of the "injury" seems to be driven by the Court's insistence, in other cases, that public accommodation of religion is not something that the hypersensitive can veto simply by invoking the Establishment Clause. In other words, even in relation to the E stablishment Clause, the Court seems to be insisting on higher standing barriers, to ensure that advocacy litigation by antireligious advocates does not preempt all claims, legal or political, of those on the other side, who seek some public accommodation of religion.

79. See $H$ arold J. K rent $\&$ E than G. Shenkman, Of Citizen Suits and Citizen Sunstein, 91 M ICH. L. REV. 1793 (1993) (articulating necessary constitutional limitations on citizen standing from this point of view).

80. 487 U .S. 654 (1988). 
into a legal imperative, which can be enforced independently of presidential policy.

What Congress has done for itself with the Independent Counsel, the law does for other interests when it acknowledges a right to sue as a private attorney general. A s the Court was unwilling to take constitutional issue with the Independent Counsel, it is unlikely to eliminate all provisions for litigation under this rubric. But it is not surprising to find the Court seeking to cut back the role of the private attorney general.

The arrangement only looked appealing when the law seemed so clear that it would not matter who brought the action. O nce applications of "the law" become contested and controversial, it matters a great deal who gets to invoke it and on what occasions and with what justification. The Independent Counsel, who was supposed to relieve Congress of the odium of partisan motivation, became embroiled himself in charges of partisanship. A nd the charges were naturally extended to the particular judges who appointed him.

Of course, any decision, even one purporting to uphold individual rights, can be controversial. But at least claims about rights avoid any confused disputes about motives and justifications. We assume that the holder of a right will invoke it in his own self-interest. In that sense, his "partisanship" is taken for granted and can hardly be hurled as a discrediting accusation. It is only the figure who purports to act for the public who can be accused of not acting properly for the real public-as some have accused Independent Counsel K enneth Starr. O nce environmental protection or civil rights claims or other such broad policy claims encounter the reality of competing interests and competing concerns, it is not easy to cover the litigation in vague talk about "public values."

The Supreme Court therefore has been unwilling either to eliminate the private attorney general or to license it openly. What it has been doing it seems, is something more modest. A t least in some areas, the Court has been cutting back on the presumption of exclusive standing for favored groups. It has, on the one hand, demanded some showing that some tangible harm would result to an identifiable group if it were not accorded legal leverage in the particular dispute. A the same time, the Court has been sharing this leverage- at least to some extent-with competing interests.

The law thus seems to be returning to more traditional patterns, where courts focus on defending individual rights rather than vindicating environmental entitlements. It is certainly suggestive that the same decade that has witnessed this tendency in the law of standing has also seen efforts by the Supreme Court to revitalize Takings Clause jurisprudence and limitations on federal regulatory power under the Commerce Clause. ${ }^{81}$ B ut as these trends have not proceeded very far, it is doubtful that retrenchments in the law of standing

81. See, e.g., Lucas v. South Carolina Coastal Council, 505 U .S. 1003 (1992) (Takings Clause); Printz v. U nited States, 117 S. Ct. 2365 (1997) (Commerce Clause); U nited States v. L opez, 514 U .S. 549 (1995) (Commerce Clause). 
will follow a rigorous logic any time soon. A rigorous application of new doctrines regarding the Takings Clause or the Tenth $A$ mendment would put at risk a vast amount of federal legislation. Too many programs now have too wellestablished constituencies to make such an upheaval politically acceptable. State governments do not clamor for rigorous enforcement of the Tenth A mendment: It would put too much of a burden on the states to renegotiate established policies, under which state politicians now escape a good deal of responsibility to make their own judgments. B usiness does not clamor for rigorous enforcement of the Takings Clause, since business firms are beneficiaries as well as victims of regulatory controls. In much the same way, Congress is unlikely to welcome a constitutional doctrine that requires Congress itself to take responsibility for writing precise statutory standards and overseeing their implementation through oversight. The private attorney general-like the alternate A ttorney General that is the Independent Counsel-can often be a considerable convenience for Congress, a device to delegate policy initiative without taking full responsibility for the consequences. Precisely to the extent that the private attorney general is seen as the instrument of a favored constituency, courts must shrink from suppressing such legal advocacy altogether. A s litigation becomes a specialized political forum, however, the Court has been willing to let a wider array of interests enter the fray. To that extent, the private attorney general has a necessarily more restricted role. 